\title{
MAJOR TRANSFORMATIONS IN CONTEMPORARY LAW AND THE TEACHINGS OF ROBERT ALEXY ${ }^{1}$
}

Luís Roberto Barroso

Professor of Constitutional Law of University of the State of Rio de Janeiro - UERJ. Masters at Yale Law School. Doctor and Full Professor by UERJ. Visiting Researcher at Harvard Law School. Minister at the Supreme Federal Tribunal.

\begin{abstract}
The text examines the three major changes of paradigm in contemporary law, seen in parallel to Robert Alexy's teachings. The author initially presents the phenomena of (i) the overcoming of legal formalism; (ii) the advent of a post-positivist legal culture; and (iii) the rise of public law and the centrality of the Constitution. The author then moves on to identify, in the work of Robert Alexy, the notion of the centrality of fundamental rights and of the Constitution, in contemporary law. The author also tackles the transformations in constitutional interpretation, focusing on (i) the recognition of the normative force of the Constitution; (ii) the expansion of constitutional jurisdiction; and (iii) the development of a new hermeneutics and of the new categories for a constitutional interpretation. Following this line, the notion of hard cases is approached against the background of ambiguity in language, reasonable moral disagreements and tensions in constitutional norms or fundamental rights. Alexy's theory of principles is then introduced to portray how law should be operated so as to solve relevant conflicts in modern society. Finally, there is an emphasis on the counter-majoritarian and representative roles of the Supreme Federal Tribunal, as well as on Alexy's writings about how constitutional tribunals carry out the argumentative representation of society.
\end{abstract}

Keywords: Robert Alexy - Contemporary Law - hard cases

1The translation was not reviewed by the author. The article was translated by Bruno Fernandes Dias, LLM candidate 2014 of International Law at University of the State of Rio de Janeiro. Public Attorney at the Attorney-General's Office of the State of Rio de Janeiro. Lawyer; and Christa Calleja, LL.M Energy and Environmental Law Katholieke Universiteit Leuven, 2012. Lawyer. 


\section{INTRODUCTION ${ }^{2}$}

It is an honour and great pleasure to be here and to share with you some ideas and reflections on the topic of the major transformations of contemporary law. And, of course, on the influence of Professor Robert Alexy's teachings in these philosophical and conceptual changes. Speaking of an author's work in his presence has always been a risk. I clearly recall the following situation I experienced when I was still a lawyer before the Supreme Federal Tribunal. Throughout the oral statements I based my arguments on excerpts from a book by Professor Eros Grau, who at the time was Minister of the Court. However, he had a personal opinion different from the one I was arguing - it was a case regarding anencephaly, which involved a legal possibility for a woman to interrupt her pregnancy - and he made an authentic interpretation of what he had written, saying that that was not what he had meant to say.

Yet worse than that, I recall a shot of a Hollywood film based on the novel of a renowned author. Questioned about his opinion on the film adaptation, he stated: "The film adaptation of my novel inspired me to write another one". So as not to run such risks, I would like to briefly tell you how $I$ have seen the transformations of contemporary law. And following that, I will aim to identify, how, in my opinion, Professor Robert Alexy's teachings have been an influence throughout this process. In doing so, I will give him the chance to say: "This fool could think what he likes, but I have nothing to do with it".

\section{THREE MAJOR CHANGES OF PARADIGM IN CONTEMPORARY LAW}

Democratic constitutionalism was the winning ideology of the $20^{\text {th }}$ century. In this institutional arrangement we find two different ideas which ran two distinct trajectories: constitutionalism, the heir to the liberal tradition which dates back to the end of the $17^{\text {th }}$ century, and which expresses the idea of power limited by Law and respect to fundamental rights. Democracy brings the idea of sovereignty of the people, of government of the majority, which was only truly consolidated throughout the $20^{\text {th }}$ century. So as to mediate the tensions which often exist between the two - that is, between fundamental rights and sovereignty of the people -, the greater part of contemporary democracies have instituted constitutional tribunals or supreme courts. Henceforth, the background within which this narrative develops includes: (i) a Constitution which guarantees fundamental rights, (ii) a

2 This text was prepared as written notes to an oral presentation, followed by a debate with Professor Alexy. The conference was held for the ocassion of bestowing of title of Professor Honoris Causae to Robert Alexy by the Federal University of Minas Gerais, on the $10^{\text {th }}$ February 2014. 
democratic regime and (iii) the existence of a constitutional jurisdiction. Well, the $20^{\text {th }}$ century saw the overcoming of certain conceptions of the classical legal thinking, which had been consolidated by the end of the $19^{\text {th }}$ century. These transformations arrived in Brazil in the final quarter of the century, especially following the redemocratization. New winds started to blow this way, as much in the academic world as well as the world of tribunal case-law, especially that belonging to the Supreme Federal Tribunal. Hereafter I pinpoint three of these transformations that affected the way in which we think and we practice Law in the contemporary world, generally, and most recently in Brazil, in particular.

1. The overcoming of legal formalism. The classical legal thinking fuelled two fictions: a) that Law, as in the juridical norm, was an expression of reason, of an immanent justice; and b) that Law would be fulfilled by means of a logical and deductive operation, whereby the judge would make a subsumption of the facts to the norms, merely pronouncing the juridical consequence already held within it. Such methodological premises - actually, ideological - did not stand the test of time. Throughout the $20^{\text {th }}$ century, an understanding was forming whereby a) Law is oftentimes not the expression of an immanent justice, but of interests which are dominant at a given place and time; and b) in a great number of situations, a solution to juridical problems is not readymade within the legal system. It would have to be argumentatively construed by the interpreter.

2. The advent of a post-positivist legal culture. It was against this background where the solution to legal problems is not found wholly in the juridical norms, that a post-positivist legal culture flourishes. If the solution is not wholly found within a norm, then we must look for it elsewhere. And, that is how the great separation which juridical positivism had imposed between Law and Moral, and between Law and other spheres of knowledge, is overcome. So as to design a solution which is not carved out in a norm, Law needs to lean on moral philosophy - in search for justice and other values -, on political philosophy - in search for democratic legitimacy and for the fulfillment of public aims which promote the public welfare - and, to a certain extent, also on applied social sciences, as are economics and psychology.

The post-positivist doctrine is inspired by the return to practical reason $^{3}$, in the theory of justice and in democratic legitimacy. Within

3 The term remains inseparably linked to Kant's work, particularly, Groundwork of the Metaphysic of Morals, of 1785 and Critique of Practical Reason, of 1788. In succinct, practical reason deals with logical groundwork - but not mathematical - of principles of morality and justice, opposing itself to scientific reason, which perceives in this discourse a mere formulation of personal opinions unable of being controlled. In a more analytical form: it concerns the use of reason aimed for the establishing of logical standards for human action. Practical reason is conceived in contrast with theoretical reason. The theoretical use of reason is characterised by 
this context, the search goes beyond strict legality, but does not scorn statutory law; one must undertake a moral reading of the Constitution and laws, but without resorting to metaphysical categories. In the summing up of rich and heterogeneous ideas which are sheltered by this paradigm in formation, we find the re-enthronement of values in juridical interpretation, with the recognition of normativity to principles and of its qualitative difference in relation to rules; the rehabilitation of practical reason and the juridical argumentation; the formation of a new hermeneutics; and the development of a theory of fundamental rights built upon the dignity of the human person. Within this context, we move closer to reconciliation between Law and ethics ${ }^{4}$.

3. The rise of public law and the centrality of the Constitution. Finally, the $20^{\text {th }}$ century has seen the rise of public law. The legal theory of the $19^{\text {th }}$ century had been predominantly built upon the categories of private law. The Century, which began with the French Civil Code, the Napoleonic Code of 1804, ended with the promulgation of the German Civil Code of 1900. The protagonist parties of Law were the contractor and the owner. Throughout the $20^{\text {th }}$ century we have seen a progressive publicization of Law, with the proliferation of norms of public order. Not only in the field of family law, as was the case traditionally, but also in areas typically held to be private, such as contract law - with the protection of the weaker side to juridical relations, such as employees, tenants and consumers - and property law, with the provision of a social function of property.

By the end of the $20^{\text {th }}$ century, this publicization of Law resulted in the centrality of the Constitution. Any legal interpretation must be made in the light of the Constitution, of its values and its principles.

the knowledge of things, not by the creation of norms. Positivism only accepted the possibility of theoretical reason. Therefore, positivist theories of law prescribed the role of science of law to be simply that of describing the law as established by the state, not of justifying norms, an operation which would not be possible by methodological rationalization. That is why, for example, according to Kelsen, it was not unto the science of law to distinguish which would be the best interpretation amongst those resulting from a determinate normative text. Such an activity would have an eminent political nature, and would always require a choice unfit for rational justification. Post-positivism, in rehabilitating the practical use of reason in juridical methodology, proposes precisely the possibility of rationally defining the norm in a concrete case by means of constructive rational artifices, which do not limit themselves to mere activity of knowing normative texts.

4 See Ricardo Lobo Torres, Tratado de direito constitucional, financeiro e tributário: valores e princípios constitucionais tributários, 2005, p. 41 (freely translated): "In the last thirty years to date, we have seen the return to values as the way to overcome positivisms. What is known as the "Kantian turn" (kantische Wende), that is, the return to the influence of Kant's philosophy, has resulted in a reconciliation between ethics and law, in the use of moral rationale to human rights and in the a search for justice based on categorical imperative. The book $A$ Theory of Justice by John Rawls, published in 1971, constitutes a certificate of rebirth of such ideas". 
Any legal interpretation is, directly or indirectly, a constitutional interpretation. The Constitution is directly interpreted when a claim is based on a constitutional text (a tax immunity, the preservation of the right to privacy); and the Constitution is indirectly interpreted when the ordinary law is applied, because prior to applying it one must verify its compatibility with the Constitution, and furthermore, the meaning and scope of the infraconstitutional norms must be demonstrated in the light of the Constitution.

\section{The teachings of Professor Robert Alexy and the Transformations of CONTEMPORARY LAW}

Professor Robert Alexy's work has influenced, or reflected, many of these transformations, in memorable texts, becoming traditional works in various parts of the world, including in Brazil. His valuable and decisive contribution into the creation of a legal "non positivist" culture (as he calls it), deserves to be mentioned, as well as into the centrality of fundamental rights - and, consequently, of the Constitution - in contemporary law.

Indeed, at the core of Professor Robert Alexy's reflections is the thesis that Law holds a double nature, with a real (or factual) dimension and an ideal one. The factual dimension manifests itself in the formal validity of the norm and in its social efficacy. The ideal dimension is manifested in its moral correctness. In homing in on the idea of moral correctness as a tertiary element, at the side of the validity and of the social efficacy, we overcome the positivist concept of Law. In fact, the most visible boundary between positivism and non-positivism is precisely found in the relations between Law and morality: whilst positivists uphold a separation between the two, the non-positivists affirm that there is a necessary linkage between them.

Well, moral correctness, a characteristic idea of Alexy's thinking, is manifested in the world of Law in the form of justice. In his textual words: "Whoever affirms that something is right, always affirms, at the same time, that it is correct"5. In this vein, Alexy refutes Kelsen's idea that "any content could be lawful", which would thus give space for the possibility of a normativity without morality. Against this vision, we find the opposing and famous formula of Radbruch's, which in succinct is pronounced as follows: "Extreme injustice is not lawful". Following this line, Alexy thinks that what it is extremely unjust is all that which offends basic human rights ${ }^{6}$. And this basic justice has

5 Robert Alexy, La institucionalización de la justicia, 2005, p. 58.

6 Robert Alexy, La institucionalización de la justicia, 2005, p. 76: (...) [T] he legal norms duly promulgated and socially efficacious which are incompatible with the core of basic human rights are extremely unjust and, therefore, are not lawful". 
universal validity ${ }^{7}$

Once these are incorporated into the Constitution, human rights become fundamental rights, and bind all state Powers and represent an opening of the juridical system before a moral system ${ }^{8}$. Fundamental rights enjoy a central position in the system, reflecting themselves in all other spheres of infraconstitutional law. This comprehensive or holistic vision of fundamental rights was originally developed by the German Federal Constitutional Tribunal, in the famous Luth case, commented by Alexy in many of his texts. In summary he states that a moral correctness of law and of legal decisions impose a binding between Law and morality. In Law, correctness equals to the idea of justice. The minimum reserve of justice corresponds to basic human rights. And these, transformed in fundamental rights by means of their inclusion in the Constitution, condition the understanding of the whole of the legal system.

\section{THE TRANSFORMATIONS IN CONSTITUTIONAL INTERPRETATION}

Most especially following the end of World War II, constitutional law suffered many profound changes in the roman-germanic world, both in terms of institutional as well as dogmatic nature. Three main changes come to the fore:

a) the recognition of the normative force of the Constitution, with the overcoming of the traditional European model within which the Constitution is perceived as a political document, a summoning of the performance of the Public Powers, especially of the Legislative. In this model, the Constitution was not seen as a juridical norm, neither did it have direct or immediate applicability.

As we know, American and French constitutionalism (and by extension, European), despite being contemporary, gave birth to diverse constitutional models. In the United States, from the very beginning, the Constitution was considered a juridical document, endowed with supremacy and normative force, susceptible to direct and immediate application by the Judiciary. In Marbury v. Madison, decided in 1803, a judicial review was accepted with relative simplicity and reduced resistance.

b) the expansion of constitutional jurisdiction, as is the creation of constitutional tribunals in the greater part of democracies in the world, since the establishment of the German Federal Constitutional

7 Point in fact, in accordance with Alexy, human rights have five elements: they are universal, fundamental, abstract, they are moral rights and they establish a priority before all other types of rights. See Robert Alexy, Discourse theory and fundamental rights. In Agustín José Menéndez and Erik Oddvar Eriksen, Arguing fundamental rights, 2006, p. 18.

8 Robert Alexy, Theory of fundamental rights, 2008, p. 29. 
Tribunal. For sure, even yet before the war the Austrian Constitutional Tribunal had already been created, however in another context and with another dimension. To a certain extent, there prevailed, in Europe, after the end of the conflict, the American model of supremacy of the Constitution and judicial control of the constitutionality of the laws (judicial review). This formula, indeed, means and to a certain extent is, a model of judicial supremacy, once that it is within the competency of a constitutional tribunal or a supreme court to ultimately interpret the meaning and scope of the Constitution.

It is in this manner that the traditional European model established in the centrality of law - not really the Constitution - and the supremacy of the parliament, is overcome. In fact, in the face of the inexistence of the control of constitutionality, the final say about the meaning and scope of the Constitution was that given by the parliament, whose performance was not susceptible to judicial control. Indeed, especially towards the mid late $20^{\text {th }}$ century, what was confirmed, finally, was the expansion of the Judiciary in a general manner. Judges and tribunals no longer integrated that which was a specialised technical department of government - instead they became an effective political power, struggling for space against the rest of the powers.

c) the development of a new hermeneutics and of the new categories for a constitutional interpretation. In the recent decades, the belief in interpretation as an activity which is purely technical and mechanical was progressively being discredited. The idea of hard cases was developed to encapsulate those cases for which no readymade solution was to be found in the legal order and thus required the creative performance of the interpreter.

\section{THE NEW CONSTITUTIONAL INTERPRETATION AND HARD CASES}

\section{The traditional constitutional interpretation}

I shall briefly describe the traditional notion of constitutional interpretation. Constitutional interpretation is a juridical interpretation modality and, as such, takes refuge in traditional elements of juridical interpretation, namely: the grammatical, the historical, the systematic and the teleological. The specificity of the constitutional norms and of the constitutional interpretation have led to the development, in time, of some specific principles of constitutional interpretation, instrumental principles, which stand as methodological assumptions the interpreter should bear in mind: the supremacy of the Constitution, the presumption of constitutionality, the interpretation in line with the Constitution, reasonableness-proportionality and effectiveness. It is not the case to 
delve into each of these principles.

In this universe of traditional interpretation, it used to be possible to define with precision the role of norms, of facts and of the interpreter. The norm should bring, in its abstract terms, a solution to juridical problems. The facts were already there ready to be framed into norms, thus allowing the syllogism which solved the problems: the law is the major premise; the facts a smaller premise; the decision a conclusion, the product of subsumption of facts to the norm; and, finally, the role of the interpreter: he carried out a technical function of knowledge, identifying the applicable norm and pronouncing the consequences of its incidence in the concrete case. An interpretation, therefore, as an act of knowledge and not of will.

\section{The new constitutional interpretation}

The new constitutional interpretation emerges to attend to those demands of a society that became much more complex and plural. It does not defeat traditional interpretation, but it comes to attend to necessities deficiently addressed by traditional formulae. It arises, among other reasons, to handle hard cases, which are those for which there are no ready-made solutions in the system. This is a crucial observation: it was not Law and the constitutional interpretation which, deliberately, have become more complicated. Life in itself became more complex, requiring more complex and subtle juridical categories.

This is how we come to the notion of hard cases. Easy cases are those for which there exists a ready-made solution in positive law. For example: a) the Constitution provides that at the age of 70 a public servant is forced to retire. If a judge, at the reaching of this age limit, files a case thereby postulating to keep his post, a solution would be given in a relatively simple manner: by mere subsumption of the relevant fact - implementation of age - in the express norm, which determines retirement; b) the Constitution lays down that the President of the Republic may only be candidate for a re-election once. If, for example, President Lula had intended to run a third mandate, the Electoral Justice would have denied to him, by a plain and simple application of the express norm. For better or for worse, not always is life as simple as that.

There are many situations in which there is no ready-made solution in Law. A solution must be created argumentatively, in the light of the elements of the concrete case, of the parameters laid down in the norm and of the external elements of Law. These are the hard cases. There are three major which bring them about:

A. Ambiguity in language. Law makes use of words which have multiple meanings or which, being indeterminate, could only be defined 
in the light of the concrete case. E.g.: a) public servant; b) relevancy and urgency; c) social interest; d) general repercussion; e) environmental impact. Many a time, the language gives rise to more than one possible interpretation.

B. Reasonable moral disagreements. In the contemporary world, in pluralistic and complex societies, as the ones in which we live, educated and well-intentioned persons think differently about themes which are morally controversial. For example: a) Euthanasia and assisted suicide, the existence or not of a right to a dignified death; b) the issue of refusal to blood transfusions for believers of the religion of Jehova Witnesses; c) the debate about the decriminalisation of soft drugs. Evidently, the disagreement must be reasonable. If an individual declares: my existential choice is paedophilia... well, I'm sorry, but this is not a morally acceptable alternative. In such a case there is no disagreement, but a contrary consensus.

C. Tensions in constitutional norms or fundamental rights. The Constitution, being a dialectic document, shelters contradictable values. Example 1: when singer Roberto Carlos had sought to prevent the publicizing of an unauthorised biography about him, there was a tension between the constitutional norms of fundamental rights, such as that which protects the right to freedom of expression and that which protects the right to a private life. Example 2: in the construction of two hydroelectric plants in the Amazon Forest, two opposing constitutional norms were likewise at loggerheads, in that particular situation: the one which provides that one of the objectives of the Republic is national development, and the other which is devoted to the protection of the environment. It must be noted that the Justice Tribunal of the State of Rio de Janeiro, in deciding the possibility of a TV broadcaster to make a programme about a crime committed many decades ago, ruled contrary to what had been ruled by the German Constitutional Tribunal when it had decided the case of the Lebach soldiers.

It is not possible to arrive at a solution for these situations by traditional means of interpretation. There is more than one possible solution and, in principle, a reasonable one, contending the choice of the interpreter. In this brave new world of constitutional interpretation, various new juridical categories were developed and refined, including: (i) the recognition that principles are norms and are qualitatively distinct in relation to rules; (ii) the setting out of the phenomenon of collisions of constitutional norms, both in regards to principles as well as in regards to fundamental rights; (iii) balancing as a technique for solutions to these conflicts, overcoming the limitations of a purely subsumptive reasoning; and (iv) the rehabilitation of juridical argumentation, of practical reason, as groundwork to legitimate judicial decisions which are not based in the traditional logic of the separation of Powers, for 
they bring about a tad of judicial creativity.

\section{Professor Robert Alexy's teachings and the transformations in constitutional interpretation}

It is in the domain of constitutional interpretation - and, notably, of interpretation of fundamental rights -, with its differing particular categories that Professor Robert Alexy's comprehensive and revolutionary contribution has been fashioned out.

The theory of the principles is one of the pillars of his theory on fundamental rights and, according to him, his system of democratic constitutionalism would be incomplete without it ${ }^{9}$. Firstly, an important observation is that principles are treated by him as a species of juridical norm. Although this would appear relatively obvious, this was an important achievement amongst us. In Brazil - and probably in other parts of the roman-germanic world - principles were thought of as a merely subsidiary source of Law, to be used only in those cases of normative lacuna and, yet so, following custom and analogy. Even those who would acknowledge constitutional principles as norms would attach to them the adjective programmatic, meaning that their effectiveness depended on a subsequent normative completion, generally the performance of the ordinary legislator. The simple acknowledgment of principles as norms, then, which emanates from Alexy's work, is readily important in itself.

Nevertheless, and yet more relevant, was the statement that the norms of fundamental rights have, oftentimes, the structure of principles. Therefore, the term principle could refer both to individual rights as well as to collective goods, that is to say, goals of public interest. And principles often collide. Consequently, we find conflicts between collective goods, between fundamental rights and between fundamental rights and collective goods. Well, in this general context, Alexy formulated his traditional qualitative distinction between rules and principles. The theme was explored to exhaustion, in academic works both in Brazil and abroad. I will hereby use the definition he used in one of his last published works in Brazil

"Principles are optimization mandates. They require that something be done in the greatest measure possible in regard to the factual and juridical possibilities. Its form of application is balancing. On the contrary, rules are norms which oblige, prohibit

9 Robert Alexy, Teoria dos direitos fundamentais, 2008, p. 85; and Robert Alexy, Principais elementos de uma teoria da dupla natureza do direito, Revista de Direito Administrativa 25, 2010 . 
or allow something definitively. In this sense, they are definite mandates. Its form of application is a subsumption" $" 10$.

Yet in the scope of the theory of principles, Alexy brings out the issue of conflicts between principles and conflicts of rules, in brilliant insights. A conflict of rules could only be solved if an exception clause is introduced therein - that is to say, the rule would not be applicable in a certain case - or by the declaration of invalidity of one of them. The conflict of principles, on the other hand, is solved in quite a different manner. If two principles collide, one shall have to give in. This does not mean, however, that it is invalid. What happens is that under certain concrete and determinate circumstances, one of them would have precedence. Under other circumstances, the solution could be opposed. A weighing or balancing is necessary so as to determine which principle has the greater weight in the concrete case ${ }^{11}$.

That brings us to another central issue in the debate concerning the constitutional interpretation: the role of balancing or weighing. Nowadays a good number of constitutional courts across the world have made use of this technique which has origin in the jurisprudence of the German Federal Constitutional Tribunal. In the German tradition, balancing is an aspect of the much more comprehensive principle of proportionality. One knows fully well that the principle of proportionality is divided into three subprinciples: adequacy, necessity and proportionality in the strict sense. Interpreting constitutional law or constitutional rights in the light of the principle of proportionality is implementing the optimization mandate inherent to the concretisation of principles. As referred above, this means carrying out each constitutional right, notably when in strain with other rights and constitutional juridical interests, in its greatest possible extension, in the light of factual and juridical circumstances to be taken into account. Alexy clarifies that the principles of adequacy and necessity refer to the optimization within the limits of the factual possibilities, given by the specific situation. On the other hand, the subprinciple of proportionality in the strict sense refers to the juridical possibilities of optimization. Balancing ultimately involves a search for the ideal solution in view of concurrent principles. Proportionality in the strict sense gives way to what Alexy coined as "The Rule of Balancing", which could be enunciated as follows: "The greater the degree of nonsatisfaction of, or detriment to, one principle, the greater must be the

10 Robert Alexy, Principais elementos de uma teoria da dupla natureza do direito, Revista de Direito Administrativo, 25. (TN: the version referred by the author was the translation by Fernando Leal', which version was used in our translation).

11 Robert Alexy, Teoria dos direitos fundamentais, 2008, p. 92 and 105. 
importance of satisfying the other" 12 .

\section{Judicialization OF Life. The COUNTER-Majoritarian AND RePresentative roles OF THE SUPREME FEDERAL Tribunal ${ }^{13}$}

As stated earlier, democratic constitutionalism was the winning ideology of the $20^{\text {th }}$ century throughout the greater part of the globe, defeating various alternative and authoritarian projects which competed with it. Such an institutional arrangement is the product of the fusion of two ideas which had two differing historical trajectories, but which came together to produce the ideal contemporary model. Democracy means people's sovereignty, the government of the people, the will of the majority. Constitutionalism, on the other hand, translates the idea of limited power and respect for fundamental rights, sheltered, as a general rule, in a written Constitution. In the traditional conception, people's sovereignty is incarnated through the elected public agents, that is: the President of the Republic and the members of the Legislative Power. On the other hand, the protection of the Constitution - that is, of the rule of law and of the fundamental rights - is attributed to the Judiciary, where at its apex, in Brazil, we find the Supreme Federal Tribunal - STF.

From this comes the duality, equally traditional, which established a rigid distinction between politics and Law, the relevance of which we discuss in this topic. In this sense, tribunals were independent and preserved from politics by means of various mechanisms (financial autonomy and the guarantees of judges, amongst others). On the other hand, they did not interfere with political concerns. For better or for worse, this time remained far behind us. Throughout the recent years, we have seen an increasing judicialization of life, a label which identifies the fact that innumerable questions of great moral, economic and social repercussions have had their final deciding instance within the hands of the Judiciary and, frequently, at the Supreme Federal Tribunal. With a critical eye, in academic or in the Parliament, many actors have reprinted the commentary made by Carl Schmidt, who was contrary to the idea of creating constitutional tribunals and spoke of

12 Robert Alexy, Teoria dos direitos fundamentais, 2008, p. 167. Amongst the main scholars in Alexy's thinking in Latin American we find, in Brazil, Virgílio Afonso da Silva (see for e.g., Direitos fundamentais - conteúdo essencial, restrições e eficácia) and, in Colombia, Carlos Bernal Pulido (see, for e.g. The rationality of balancing, accessible at http://www.upf.edu/ filosofiadeldret/_pdf/bernal_rationality_of_balancing.pdf). Both were translators into Spanish and Portuguese, respectively, of the traditional works of Alexy, as referred within this note. 13 The ideas expressed within this topic were originally presented in: Luís Roberto Barroso and Eduardo Mendonça, STF entre seus papéis contramajoritário e representativo, 2013. Available at http://www.conjur.com.br/2013-jan-03/retrospectiva-2012-stf-entre-papeiscontramajoritario-representativo. 
the risks of judicializing politics and of politicizing justice. This goes contrary to Hans Kelsen, who has defended those Tribunals. It is not the case to come back to this debate, which work has already been done in other academic works by this author ${ }^{14}$.

It would be relevant to highlight at this juncture how the Court clearly carries out two distinct and apparently opposing roles. The first role is named, in constitutional theory, as the counter-majoritarian: on behalf of the Constitution, of the protection of the rules of the democratic game and of the fundamental rights, it is up to the Court to declare the unconstitutionality of laws (i.e., the majoritarian decisions taken by Congress) and of acts of the Executive branch (whose head was elected by the absolute majority of citizens). This means: non-elected public agents, such as judges and Ministers of the STF, may superimpose their own reasoning to that of the traditional representatives of the political majority. Hence the term counter-majoritarian. The second role, less discussed in constitutional theory ${ }^{15}$, could be referred to as representative. This emerges, as the name suggests, when the Tribunal attends to public demands and political ambitions not timely attended to by the National Congress.

This representative role of the Supreme Federal Tribunal has awoken great attention in recent times. It has imposed a reflection about the relations of the Court with society and with the other Powers. The capacity of a constitutional court to interpret and take into account the societal sentiment is positive and desirable. In a democracy, all power is representative; that means it must be exercised in the name and in the interest of the people, as well as must be accountable to society. For this reason, judges of whichever degree of jurisdiction must look through the window of their chambers and make an effort to understand the reality around them. But one must be cautious: the Judiciary cannot become yet another channel of the political majority, subservient to the public opinion or influenced by the media. Many times, the right solution is not the most popular one. And judicial populism is just as bad as any other.

In gleaning on the relations with the other Powers of the state, one must also be cautious. In Brazil, the Legislative branch is going through a difficult moment, a certain crisis of representativeness and functionality. Despite the clear perception of the phenomenon, the

14 See Luís Roberto Barroso, O controle de constitucionalidade no direito brasileiro: exposição sistemática da doutrina e análise crítica da jurisprudência, 2011, p. 74-5.

15 See, meanwhile, Corinna Barret Lain, Upside-down judicial review, The Georgetown Law Journal 101: 113, 2012; Thamy Pogrebinschi, Judicialização ou representação: política, direito e democracia no Brasil, 2011; and Luís Roberto Barroso, O constitucionalismo democrático no Brasil: crônica de um Sucesso Imprevisto. In: Luís Roberto Barroso, O novo direito constitucional brasileiro, 2012, p. 41. 
political leaderships have not managed, as yet, to advance an agenda of reforms, particularly of political reform. This increases the pressure upon the Judiciary, many a time provoked by those very political agents in engaging on those controversial issues. Other times, entities of civil society or private parties postulate judicially certain claims of society which have gotten stuck in the middle of the political majoritarian process. Although an expansive position by the Court may, many times, seem inevitable, one needs to avoid judicial arrogance or any hegemonic claims. In this issue, as in everything else in life, it is essential to get things right at the proper degree.

On the occasion of my hearing before the Federal Senate, which took place on the $5^{\text {th }}$ June 2013 , I put forth my point of view on the matter. In the ideal world, politics is politics, law is law. They are different spheres. In the real world, however, the boundaries are almost never clearly delineated. And that is how inevitable tensions arise. When this happens, it is important to have criteria to set out the issue. I believe that here we could distinguish two situations: a) when there has been a performance of the Legislative or of the Executive in regard to the issue; and b) when there has not been such performance.

In the first scenario, therefore, we find the Legislative having effectively deliberated a determinate issue. For example: (i) the enactment of a law permitting and regulating research of embryonic stem cells; or (ii) the enactment of a law regulating affirmative action in favour of black people. In these two cases, despite there being a political controversy, the Judiciary must be deferent to the choices made by the Legislative. It is not unto the Judiciary to superimpose its own political assessment towards organs whose members have been baptised by popular representation.

A different situation arises when the Legislative would not have performed, either because it could not, or it did not want to or it did not manage to form a majority. In such a case there would exist a lacuna in the system. But the problems will take place and the Judiciary will have to deal with them. For example: a) Congress would not have as yet regulated strikes in the public service. Notwithstanding, strikes did take place, disputes arose and the STF had to establish rules to be applied until the Congress would provide some regulation on the subject. Or b) the case of homosexual relations. They exist. They are a fact of life, irrespective of what each person may think on the matter. There is no law in its regard. Well, the State must take a position about the existence or not of the rights of these couples to be recognised as a familial entity, for the moral importance of this acknowledgement and for a series of practical questions (inheritance, alimony, division of common assets). When Congress does not furnish a reply, it is obvious that those affected will bring their claim before the Judiciary, seeking a judicial affirmation 
of that which the political end failed to discuss.

It is natural that a constitutional court could also, in principle, review a legislator's choice, but this would obviously involve a higher argumentative onus. This is why the Judiciary's role, when a political deliberation is lacking, is more comprehensive than what would have taken place should there be such a deliberation. If there is a law, the STF could only invalidate it if it is unequivocally at loggerheads with the Constitution. If there is no law, the Judiciary could not abandon the case due to normative omission. In such a case, its power expands. Therefore, deep down, the power over the greater or minor degree of judicialization is of no other than Congress itself: when it performs, judicialization reduces; and vice versa.

\section{Professor Robert Alexy's teachings and constitutional jurisdiction: the Constitutional Tribunal as Argumentative REPRESENTATION OF SOCIETY ${ }^{16}$}

Constitutional jurisdiction is a manifestation of state power, of political power. In a democracy, as we have already mentioned, all political power emanates from the people, and naturally, must be exercised in its name. Consequently, all legitimate political power is a representative power. But members of a constitutional court are not elected, as are congressmen, neither are they subject to control, considering there is no option to refuse to re-elect them. The only manner to reconcile constitutional jurisdiction with democracy is to conceive it, also, as a popular representation. To reach this, there are two obstacles to overcome: it is necessary to (i) untie representation from election; and (ii) to demonstrate why the representation by the constitutional tribunal must have precedence upon the representation based on the elections.

In Alexy's view, the key to the solution of these problems and, consequently, to the general problem of constitutional jurisdiction, is the concept of argumentative representation. As a matter of fact, it is possible to sketch a model of democracy which is not exclusively based on the concepts of elections and of the government of the majority. A model of this kind would be purely decisional. But the adequate concept of democracy must include not only decision, but also argument. With the inclusion of the idea of arguments, the democracy is converted into a deliberative democracy. In this sense, the representation of the people by the parliament must be decisional as much as argumentative

16 The ideas presented in this topic where gathered in Robert Alexy, Balancing, constitutional review and representation, International Journal of Constitutional Law 3:572, 2005, p. 578 et seq. 
or discursive. On the other hand, the representation of the people by a constitutional court is purely argumentative. One must see how the adequate concept of representation must be connected with some ideal value $^{17}$. Representation must intend to be correct.

The critique which is made of the constitutional jurisdiction and of the role of the constitutional courts is that this is an idealisation. And that, ultimately, a simple claim of representation of the people would turn any argument a legitimate one, without limit or control. Such objection could be counter-argued on showing two points: a) there are arguments which could be considered solid and correct; and b) rational people are capable to accept solid and correct arguments. Once these conditions exist, it can be made out how discursive constitutionalism is a project of institutionalisation of reason and of correctness. This means: if there are solid and correct arguments, as much as there are rational people, reason and correctness are best institutionalised with the existence of constitutional jurisdiction, much more than in its absence.

\section{Conclusion}

Intention for moral correctness, principles as optimisation mandate, rule of balancing, fundamental rights as minimal content of the idea of justice, the constitutional court as argumentative representation of society: both the grammar and the semantics of contemporary constitutional law, as well as the language of a great number of constitutional courts in the world, include the categories and terminologies of Professor Robert Alexy. Few authors have the projection and influence as the one he has reached. All this without any marketing, without political or economic interest, unpretentiously and without arrogance, but solely for the virtue of which he has been made a symbol: the virtue of rationality and of the quality of argument. And since Professor Robert Alexy was a person who contributed to universalise proportionality and balancing, I would like to conclude my presentation with an excerpt from the Chinese philosopher Lao-Tsé, taken from his classical work Tao Te Ching, written over 2,600 years ago, and which makes justice to our honoured guest:
"An excess of light blinds the human eye.
An excess of noise ruins the ear.
An excess of condiments deadens the taste.
The effect of too much horse racing and hunting is bad,
And the lure of hidden treasure tempts one to do evil.

17 This expression is used by Alexy, who attributes it to Gerhard Leibholz. Robert Alexy, Balancing, constitutional review, and representation, International Journal of Constitutional Law 3:572, 2005, p. 579. 
Therefore, the wise man attends to the inner significance of things, And does not concern himself with outward appearances".

\section{REFERENCES}

ALEXY, Robert. La institucionalización de la justicia, 2005.

. Balancing, constitutional review and representation, International Journal of Constitutional Law 3, 2005.

. Discourse theory and fundamental rights. In: Menéndez Agustín José; Oddvar Erik Eriksen, Arguing fundamental rights, 2006.

. Principais elementos de uma teoria da dupla natureza do direito, Revista de Direito Administrativo 25, 2010.

. Teoria dos direitos fundamentais, 2008.

BARROSO, Luís Roberto. O constitucionalismo democrático no Brasil: crônica de um Sucesso Imprevisto. In: Barroso, Luís Roberto, O novo direito constitucional brasileiro, 2012.

direito brasileiro: exposição sistemática da doutrina e análise crítica da jurisprudência, 2011, p. 74-5.

BARROSO, Luís Roberto; MENDONÇA, Eduardo. STF entre seus papéis contramajoritário e representativo, 2013. Disponível em http:// www.conjur.com.br/2013-jan-03/retrospectiva-2012-stf-entre-papeiscontramajoritario-representativo.

KANT, Emmanuel. Groundwork of the Metaphysic of Morals, 1785. . Critique of Practical Reason, 1788.

LAIN, Corinna Barret. Upside-down judicial review, The Georgetown Law Journal 101: 2012.

POGREBINSCHI, Thamy. Judicialização ou representação: política, direito e democracia no Brasil, 2011.

TORRES, Ricardo Lobo. Tratado de direito constitucional, financeiro e tributário: valores e princípios constitucionais tributários, 2005. 